\title{
Internal Stakeholder Engagement, Organizational Support, Project Team Efficacy and Project Success. A Case Study of USAID aided Projects in Uganda.
}

\author{
Brenda Kanyesige ${ }^{a}$
}

a Makerere University

\begin{abstract}
\end{abstract}

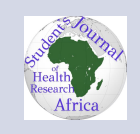

Background:

This study examined the relationship between internal stakeholder engagement, organizational support, project team efficacy and project success among USAID projects in Uganda. The objectives were: to examine the relationship between internal stakeholder engagement and project team efficacy; organizational support and project team efficacy; project team efficacy and project success; and to examine the mediating effect of project team efficacy.

\section{Methodology:}

The study applied a cross-sectional research design with a quantitative research approach. A sample of 44 projects was obtained by simple random sampling from a total of 50 ongoing projects. Data was collected using a structured questionnaire. Validity of the instrument was determined by expert judgment and Cronbach Alpha for reliability. Data was analyzed using SPSS v.25 to obtain frequencies, descriptive statistics, factor analysis and inferential statistics in data presentation and interpretation.

\section{Results:}

Findings established a positive relationship between stakeholder engagement and project team efficacy. The findings also found a positive relationship between organizational support and project team efficacy. There was a positive relationship between project team efficacy and project success. More so, findings obtained that project efficacy is a significant mediator in the relationship between organizational support and project success, but not significant in mediating the relationship between internal stakeholder engagement and project success. The findings further observed that the best predictor of project success is project team-efficacy.

\section{Conclusion:}

Internal stakeholder engagement, organizational support and project team efficacy are critical in project success. As far as project success is concerned, the factors take center stage. Moreover, project managers should concentrate most towards project team efficacy.

\section{Recommendations: ${ }^{a}$}

Delegation of responsibilities; effective communication; understanding the strength and weaknesses of each team member; leading by example; and holding meetings frequently.

\footnotetext{
${ }^{a}$ submitted: 26th/8/2021 accepted: 10th/9/2021 email: brendakanye@gmail.com
} 


\section{Background}

The project-based approach has become a primary operational model for most organizations ( $\mathrm{Wu}$, Zhao, Zuo \& Zillante, 2018). To achieve their strategic goals, organizations have found it inevitable to implement activities through projects (Anantatmula, 2010). Typically, such projects have predetermined time, budget, scope, and beneficiary satisfaction factors upon which success is gauged (Handzic, Durmic, Kraljic \& Kraljic, 2016; Lechler \& Dvir, 2010). However, what project implementers need to do to fulfill these criteria remains has been voiced as a perennial and troublesome problem among projects (Williams, 2016). Some of the empirical studies have highlighted that internal stakeholder engagement, organizational support, and project team-efficacy are important in ensuring project success (Ahmed \& Nawaz, 2015; Ojwang \& Bwisa, 2014; Yaakobi \& Weisberg, 2018).

Internal stakeholders are considered to have a direct linkage to activities that take place within a project (Freeman, 2010). Due to their contractual obligation, it is indicated that their engagement is critical in ensuring that project activities are implemented as planned to avoid delays and alterations (Kaur \& Lodhia, 2018). Internal stakeholder engagement enhances focus, commitment, and determination among internal stakeholders to fulfill tasks as planned. On the other hand, it is highlighted that whenever organizational support exists, project members develop a sense of belonging and attachment which makes them more accountable and highly determined to achieve project goals within the appropriate time, scope, and budget (Newton, 2015).

Bandura (2000) also explains that team-efficacy is task-specific and is concerned with a team's shared belief in its ability to perform a designated task or to meet a specified goal. Kähkönen, Keinänen, and Naaranoja (2013) postulate that the perceived capabilities of the team explain its achievement potential since it enhances confidence and determination among members towards the project. Highly efficacious teams prefer to associate with success work towards contributing to such success.

United States Agency for International Development (USAID) remains committed to aiding organizations as implementing partners to improve Ugandans' livelihoods since 1962, in peace and security, democracy and governance, health and education, economic growth, and humanitarian assistance. In 2014, USAID diverted funding for HIV/AIDS programs from the Inter-religious Council of Uganda. This was because the organization's top management deviated from the project's goal to fit in their mandate which led to exclusion of some beneficiaries thus failing the project's intended purpose (Kwesiga, 2014). The internal stakeholders felt disengaged since they had different views from both the implementing organization and the donor (USAID). This confusion led to beneficiary unsatisfactory that rendered failure to the project achieving its intended purpose.

USAID Literacy Achievement and Retention Activity assessment, a project implemented by RTI international to support the early grade reading program of the Government of Uganda has been associated with dismal success (USAID Annual Report, 2017). Budget overruns in the teacher professional development funds have consistently increased. Headteachers are also not supportive enough in organizing sessions and ensuring staff attends much as such programs have consistently been funded. It is highlighted that absenteeism, inadequate dedication, and vigor to the project's activities of headteachers and teachers could be primary in these shortfalls (USAID Annual Report, 2017).

Much as project failures continue to be reported across USAID-aided projects, limited empirical studies have been conducted to investigate the extent to which factors of internal stakeholder engagement, organizational support, and project teamefficacy could be responsible. Instead, most of the studies available have largely been conducted in developing countries (Shah \& Naqvi, 2014; Yong \& Mustaffa, 2013; Zhang \& Fan, 2013), and are not specific to donor-aided projects. It is against this background that this study is conducted to that effect.

The prevalent volatile environment has risen to new prominence, and organizations have been pressed hard to ensure project success in terms of meeting the cost, time, quality requirements, and ensuring beneficiary satisfaction (Prabhakar, 2009). In Uganda, USAID has sponsored several projects such as Strengthening Uganda's Systems for treating AIDS patients nationally (SUSTAIN), Malaria Action Program for Districts (MAPD)/Malaria, literacy, and Education Program, peace and security as well as economic growth and development. This support is in form of training programs for projects 
teams, providing financial assistance to facilitate the project activities, providing opportunities for Ugandan products to reach the American consumers, and developing a strong partnership with the American military to build a professional force that contributes to peace and security across the region (Report to the Ugandan People, September 2016). However, some of these projects have been characterized by cost and budget overruns. As a consequence, USAID may be prompted to reduce its support to Uganda. The inadequate project success among USAID aided projects may likely be attributed to inadequate internal stakeholder engagement, organizational support, and low project team efficacy exhibited among such projects. Locally, there is scarce empirical data to show the extent to which this is true, impelling the researcher to seek further inquiry.

\section{METHODOLOGY \\ Research design}

In line with Babbie's (2010) observation that research needs to adopt a research design that is suitable to acquire and analyze data, a cross-sectional survey design was adopted for the study. The design entails collecting data once without repeating it in subsequent times, a quantitative approach was applied. This approach involved collecting data that is statistically analyzed and presented in such forms of correlation and regression (Maxwell, 2012). The quantitative data was selected since it addresses the nature of the relationship and the magnitude of such a relationship (Field, 2009).

\section{Study population}

The population constituted 50 ongoing USAIDfunded projects in Uganda (F. Onyango, USAID Executive Director, March 19, 2018).

\section{Sample Size}

The study used a sample of 44 USAID-funded projects and this was determined based on the Krejcie and Morgan (1970) table of determining the samples from a given population. These projects were regarded as the unit of analysis. From each project, a minimum of 4 respondents (two senior officers and two low senior staff) were selected to serve as the unit of inquiry.

\section{Response rate}

Out of 44 USAID-funded projects which were targeted, 34 were able to accept giving a response rate of $77.3 \%$.

\section{Demographic Characteristics}

The study used frequency tables to indicate both individual and organizational characteristics which participated in the study. The project characteristics on the other hand include the type of project, project duration, number of beneficiaries, and the cost per project. The results are shown in Table 1. The individual characteristics obtained include sex, marital status, age bracket, education, years of service, and the current position. These results are summarized in Table 2.

\section{Source: Primary Data}

Table 2: Factor Structure for Project TeamEfficacy

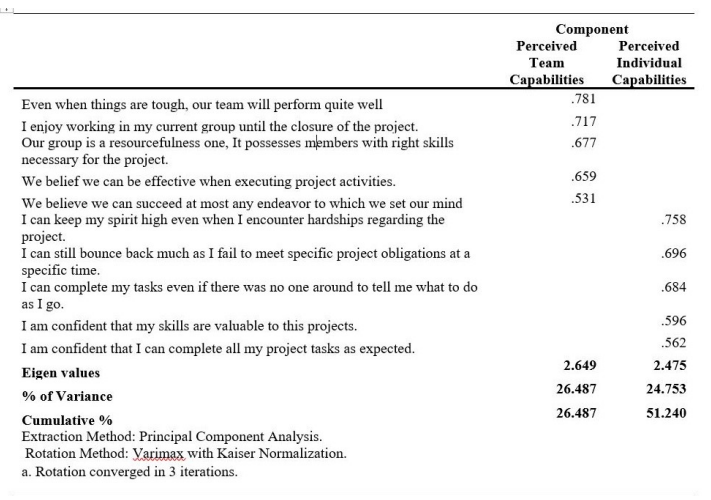

\section{Source: Primary Data}

Results from Table 2 indicate that perceived team capabilities are responsible for $26.487 \%$ and perceived individual capabilities $24.753 \%$ of the aggregated variance of $51.240 \%$ in project success resulting from project team efficacy. From the Eigen total values of perceived team capabilities (2.649) and perceived individual capabilities (2.475), it is conclusive that the most significant measure of project team efficacy is perceived team capabilities.

\section{Inferential Statistics}

The study used both correlation analysis and regression analysis to provide answers to research questions.

\section{Correlation Analysis}

Correlation analysis was used to determine the relationship between the indicated variables. A correlation analysis is a statistical function used for testing a relationship between two or more variables. In this research, a positive and negative correlation is used to indicate the nature of the relationship. The study also indicates the significance level of the relationship ( $95 \%$ or $99 \%)$. The results obtained are summarized in Table 4. 
Table 1. Project Characteristics

\begin{tabular}{lll}
\hline $\begin{array}{l}\text { Characteristic } \\
\text { Type of the project }\end{array}$ & Frequency & Percent \\
Health & 16 & 46.2 \\
Education & 13 & 37.9 \\
Economic growth \& Dev't & 2 & 6.1 \\
Security \& Governance & 1 & 3.0 \\
Environment \& Climate & 2 & 6.8 \\
Total & 34 & 100.0 \\
Project Duration & & \\
1 year or less & 4 & 12.1 \\
2-5 years & 30 & 87.9 \\
Total & 34 & 100.0 \\
Number of beneficiaries & & \\
Less than 1000000 & 1 & 3.0 \\
1000000-2000000 & 2 & 6.8 \\
2000001-3000000 & 5 & 13.6 \\
3000001 and above & 26 & 76.5 \\
Total & 34 & 100.0 \\
Cost of Project (in million \$) & & \\
Between 1 and 50 & 11 & 33.3 \\
51-100 & 23 & 66.7 \\
Total & 34 & 100.0 \\
\hline
\end{tabular}

Table 2. Pearson Correlation Results

\begin{tabular}{|c|c|c|c|c|c|c|c|c|c|c|c|c|c|}
\hline Variable/Construct & 1 & 2 & 3 & 4 & 5 & 6 & 7 & 8 & 9 & 10 & 11 & 12 & 13 \\
\hline $\begin{array}{l}\text { Internal Stakeholder } \\
\text { Engagement (1) }\end{array}$ & 1 & & & & & & & & & & & & \\
\hline Vigor (2) & $.785^{* *}$ & 1 & & & & & & & & & & & \\
\hline Dedication (3) & $.800^{* *}$ & $.608^{* *}$ & 1 & & & & & & & & & & \\
\hline Absorption (4) & $.814^{* *}$ & $.365^{* *}$ & $.532^{* *}$ & 1 & & & & & & & & & \\
\hline $\begin{array}{l}\text { Organizational Support } \\
\text { (5) }\end{array}$ & $.420^{* *}$ & $.492^{* *}$ & $.321^{* *}$ & $.312^{* *}$ & 1 & & & & & & & & \\
\hline Managerial Support (6) & $.459^{* *}$ & $.515^{* *}$ & $.366^{* *}$ & $.330^{* *}$ & $.472^{* *}$ & 1 & & & & & & & \\
\hline Resource Allocation (7) & $.523^{* *}$ & $.618^{* *}$ & $.453^{* *}$ & $.335^{* *}$ & $.772^{* *}$ & $.676^{* *}$ & 1 & & & & & & \\
\hline Job Condition (8) & $.380^{* *}$ & $.446^{* *}$ & $.340^{* *}$ & $.220^{*}$ & $.525^{* *}$ & $.788^{* *}$ & $.644^{* *}$ & 1 & & & & & \\
\hline Project Team Efficacy (9) & $.391^{* *}$ & $.422^{* *}$ & $.289^{* *}$ & $.282^{* *}$ & $.425^{* *}$ & $.281^{* *}$ & $.459^{* *}$ & $.233^{* *}$ & 1 & & & & \\
\hline $\begin{array}{l}\text { Perceived Individual } \\
\text { Capabilities (10) }\end{array}$ & $.371^{* *}$ & $.361^{* *}$ & $.287^{* *}$ & $.263^{* *}$ & $.350^{* *}$ & $.223^{*}$ & $.357^{* *}$ & $.201^{*}$ & $.888^{* *}$ & 1 & & & \\
\hline $\begin{array}{l}\text { Perceived Team } \\
\text { Capabilities (11) }\end{array}$ & $.335^{* *}$ & $.398^{* *}$ & $.236^{* *}$ & $.246^{* *}$ & $.411^{* *}$ & $.280^{* *}$ & $.463^{* *}$ & $.217^{*}$ & $.912^{* *}$ & $.620^{* *}$ & 1 & & \\
\hline $\begin{array}{l}\text { Performance Feedback } \\
\text { (12) }\end{array}$ & .027 & .053 & .017 & .041 & .095 & .041 & .001 & .048 & $.197^{*}$ & .113 & $.235^{* *}$ & 1 & \\
\hline $\begin{array}{l}\text { Project Success ( } 13 \text { ) } \\
\text { **. Correlation is significal } \\
\text { level ( } 2 \text {-tailed). }\end{array}$ & $\begin{array}{l}.423^{* *} \\
\text { ht at the }\end{array}$ & $\begin{array}{l}.394^{* *} \\
0.01 \text { I }\end{array}$ & $\begin{array}{l}.311^{* *} \\
\text { level }(2-\end{array}$ & $\begin{array}{r}.367^{* *} \\
- \text {-tailed), }\end{array}$ & $\begin{array}{l}.548^{* *} \\
* \text {. Corr }\end{array}$ & $\begin{array}{l}.316^{* *} \\
\text { rrelatior }\end{array}$ & $\begin{array}{l}.544^{* *} \\
\text { n is sigr }\end{array}$ & $\begin{array}{l}.253^{* *} \\
\text { snificant }\end{array}$ & $\begin{array}{l}.732^{* *} \\
t \text { at the }\end{array}$ & $\begin{array}{l}.626^{* *} \\
0.05\end{array}$ & $.688^{* *}$ & .141 & 1 \\
\hline
\end{tabular}




\section{Source: Primary Data \\ Internal Stakeholder Engagement and Project Team Efficacy}

Table 3 Indicates a significant positive relationship between stakeholder engagement and project team efficacy $(r=.391, p<0.01)$. According to these statistics, having internal stakeholder engagement in place is likely to enhance project success. Worth noting, internal stakeholder engagement has subcomponents of vigor, dedication, and absorption. The result reveals a significant positive relationship between vigor and project team efficacy ( $r=.422$, $p<0.01)$. Further, a correlation ( $r=.289)$ at a significant level of $99 \%$ was obtained about dedication and project team efficacy. The results further reveal a significant positive relationship between absorption and project team efficacy $(r=.282, p<0.01)$. These statistics signify that vigor, dedication, and absorption are all necessary for enhancing project success. The above results address research question one.

Organizational Support and Project Team Efficacy

Correlation results in Table 3 indicate a significant positive relationship between organizational support and project team efficacy $(r=.425, p<.01)$. The results imply that project success among donorfunded projects would be enhanced with organizational support. Organizational support also has sub-variables of managerial support, resource allocation, and job condition. The results obtained a significant and positive relationship between managerial support and project team efficacy $(r=.281$, $p<.01)$. Similarly, a significant and positive relationship was exhibited between resource allocation and project team efficacy $(r=.459, p<.01)$ and job condition and project team efficacy $(r=.233, p<.01)$. These results signify that each of the constructs for organizational support is necessary for enhancing project success. The above results address research question two.

\section{Project Team Efficacy and Project Success}

Table 3 Indicates a significant and positive relationship between project team efficacy and project success $(r=.732, p<.01)$. In this regard, the results imply that enhancing project team efficacy is likely to enhance project success. Worth noting, project team efficacy is explained by constructs of perceived individual capabilities, perceived team capabilities, and performance feedback. The results indicate a significant positive relationship between perceived individual capabilities and project success $(r=.626, p<.01)$. In addition, the results indicate a significant and positive relationship between project team capabilities and projects success with a correlation of $(r=.688, p<.01)$ at a significance level of $(p<.01)$. On the other hand, the statistic reveals that the relationship between performance feedback and project success is positive although not significant $(r=.141, p<.01)$. These results imply that only perceived individual capabilities and perceived team capabilities components are necessary for enhancing project success. The above results address research question three.

\section{Testing the Mediation Effect}

This study used a hierarchical multiple regression model to examine the mediating effect of perceived team efficacy in the relationship between individual stakeholder engagement, organizational support, and project success. We apply the normal theory approach developed by Sobel (1982) and Baron and Kenny (1986). Sobel test was conducted using Jose's Medigraph for each variable to confirm the mediation. According to Baron and Kenny (1986), four conditions must be fulfilled to conclusively state a significant relationship. First, the variations in the independent variable significantly account for variance in the presumed mediator. Secondly, the variations in the mediator significantly account for variance in the dependent variable. Thirdly, the variations in the independent variable significantly account for variance in the dependent variable. Lastly, the effect of the independent variable on the dependent variable significantly reduces when the mediator is included in the equation.

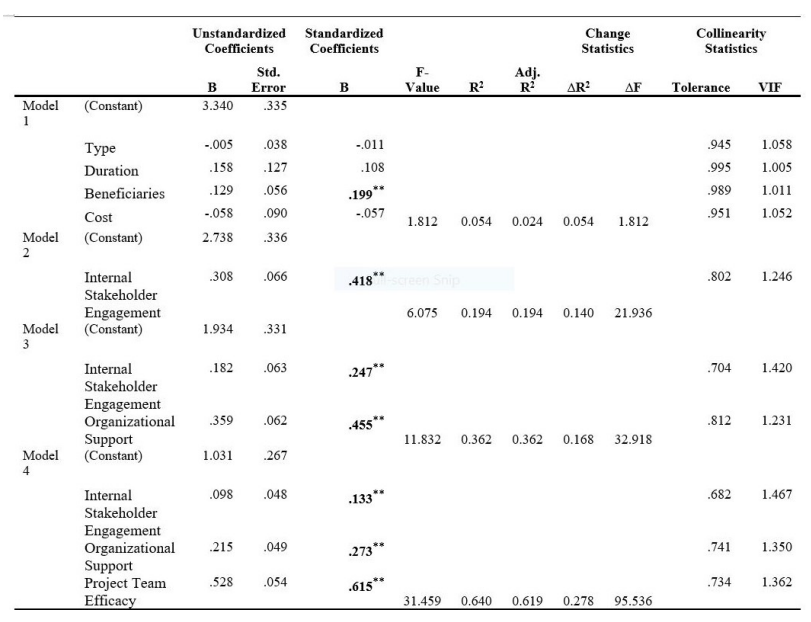

\footnotetext{
Source: Primary Data

Source: Primary Data
} 


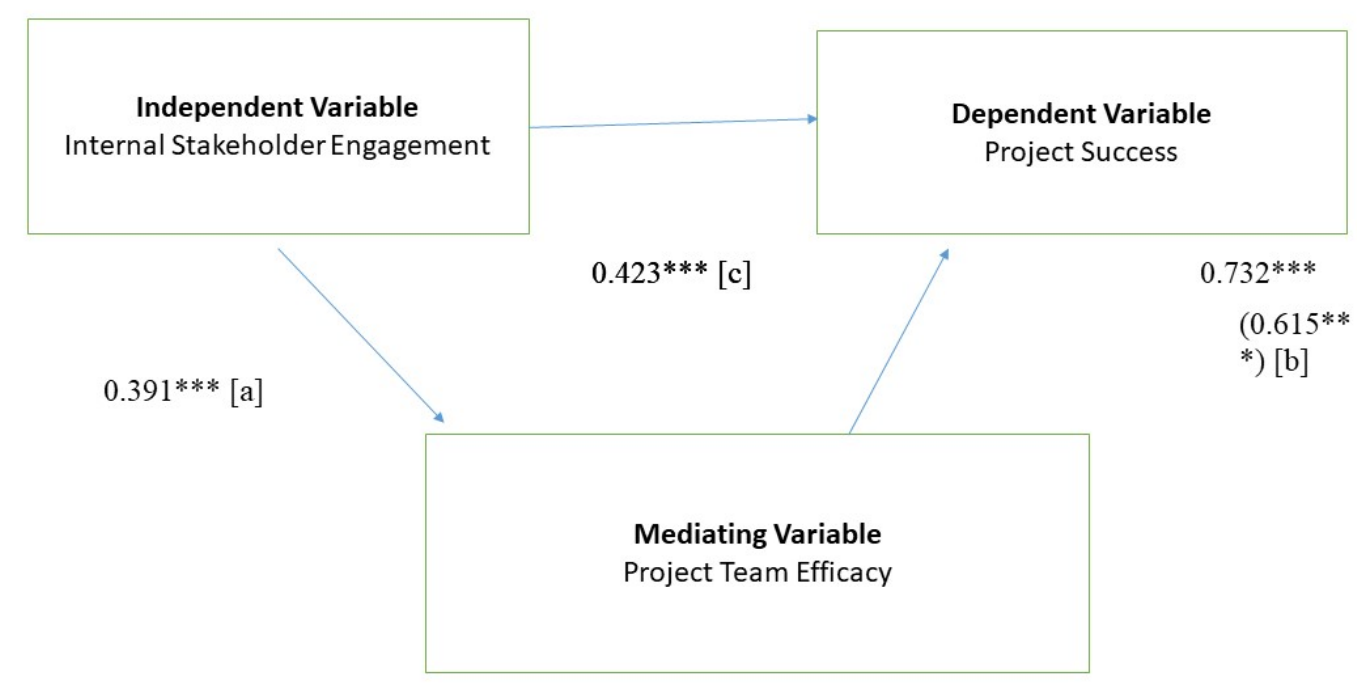

Figure 1. Mediating Effect of Project Team Efficacy in the relationship between Internal Stakeholder Engagement and Project Success

Figure 2: Mediating Effect of Project Team Efficacy in the relationship between Organizational Support and Project Success

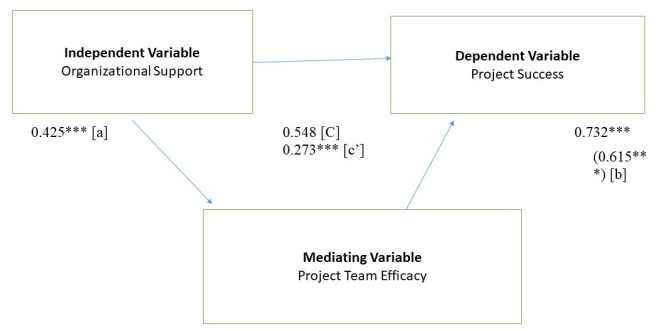

\section{Source: Primary Data}

From Table above, the study indicates $\Delta \mathrm{r} 2$ $=.14$ about internal stakeholder engagement and project success. The results imply that 14 percent of the variance in project success would emanate from internal stakeholder engagement. In addition, $\Delta r 2=.16 .8$ obtained about organizational support signifies that a potential 16.8 percent in project success results from this variable while $\Delta \mathrm{r} 2=.278$ corresponding to project team efficacy suggests that 27.8 percent of the variance in project success emanates from project team efficacy. Henceforth, the result signifies that project success is mostly explained by project team efficacy.

About testing the mediation, studies reveals that there exists a relationship between the variables meant to be mediated. Notable, $r 2=.194, F=6.075$, $p<0.01$ about internal stakeholder engagement and $\mathrm{r} 2=.362, \mathrm{~F}=11.832, \mathrm{p}<0.01$ about organizational support is obtained in this regard. In addition, the results indicate that there exists a relationship between internal stakeholder engagement, organizational support, project team efficacy, and project success $(r 2=.640, F=31.459, p<0.01)$. The beta coefficient of the mediator is also significant in regression model $3(\beta=.615 ; p<0.01)$ when all variables are regarded as independent. More so, the model indicates that the impact of organizational support declines ( $\beta=.455$ to $\beta=.273$ ) as well as internal stakeholder engagement ( $\beta=.418$ to $\beta=.133$ ) once the mediator is included in the model. In this regard, the results suggest that project team efficacy is a significant mediator.

Figures 1 and 2 both reveal that project team efficacy significantly mediates the relationship between organizational support and project success as well as the relationship between internal stakeholder engagement and project success. Overall, 
the results indicate a ratio index of 68.6 percent given by $(0.290 / 0.432 * 100)$, signifying that 68.6 percent of the effect of internal stakeholder engagement on project success goes through project team efficacy while 31.4 percent of the effect is direct. On the other hand, Figure 4.2 reveals that 50.2 percent of the effect of organizational support on project success is direct while 49.8 percent is indirect.

\section{DISCUSSION, CONCLUSION, AND RECOMMENDATION OF FINDINGS}

\section{Introduction}

This chapter presents the discussion, conclusion, and recommendation of findings based on the study objectives of the study.

\section{Discussion of Findings}

The findings of this study are compared and contrasted with previous scholarly literature to indicate the addressed knowledge gap.

\section{Internal Stakeholder Engagement and Project Team Efficacy}

The findings obtained that there exists a positive relationship between internal stakeholder engagement and project team efficacy. In this regard, it is conclusive that improving project team efficacy necessitates the improvement in internal stakeholder engagement. These results are in line with Missonier and Fedida (2014) who revealed that internal stakeholder engagement stimulates individual commitment hence driving employees' confidence towards the project. In the same line, Beringer et al., (2013) concluded that the heart of any project is purely vested in internal stakeholder engagement. The consistency exhibited suggests that when internal stakeholder engagement is stimulated, stakeholders would exhibit more dedication, vigor, and absorption in their work to which would improve their overall knowledge and competencies. This would improve their perceived individual capabilities and perceived team capabilities which are critical components for project team efficacy. This is in line with Bal et al., (2013) who expressed the need for internal stakeholder engagement indicating that its manifestation drives confidence and belief among team members. Henceforth, the findings signify the need for projects to take considerable attention to practices that could improve internal stakeholder engagement as far as improving project team efficacy is concerned.

Worth noting, internal stakeholder engagement is a multidimensional concept explained in terms of vigor, dedication, and absorption. The findings obtained that each of the dimensions is necessary for enhancing project team efficacy. These findings supplement Fulton et al., (2013) who revealed that engagement promotes perceived individual capabilities which emanate from a series of tested performances by the individual contributing significantly to project team efficacy. Within the same context, this study postulates that the efficacy of team members is more likely to occur where there is vigor, dedication, and absorption. This is in line with Tengan and Aigbavboa (2017) who emphasized that vigor, dedication, and absorption tendencies are more likely to build mutual trust among individual members directed towards one objective. Likewise, Heravi et al., (2015) viewed that internal stakeholder engagement promotes togetherness and collectivism in approaching tasks of the project which increases the confidence of members. While this is the case, the findings observe that perhaps, projects should put much emphasis on practices that drive stakeholders to become vigorous. Unlike other studies, this study comprehensively scrutinizes the relevance of the internal stakeholder engagement components, which is a value-adding to the existing research.

Specifically, the findings elaborate that vigor would drive project team efficacy. These findings are consistent with Ojwang and Bwisa (2014) who revealed that vigor stimulates the desire to execute tasks and responsibilities of the project, minimizes conflict of interest, promotes a sense of ownership, and facilitates partnership among group members. Based on this finding, the study postulates that whenever stakeholders feel passionate, resilient, and determined to persevere at work, they are likely to gain self-confidence and trust the team in which they are part and parcel. In addition, the study reemphasizes that vigor would increase the zeal of the group and a spirit of togetherness. This is in line with Beringer et al., (2013) who emphasized that project managers should direct much attention towards enhancing employees' vigor since absorption and dedication are more likely to prevail in such circumstances. Similarly, Tengan and Aigbavboa (2017) established that once employees have vigor it is important in enhancing per- 
ceived individual capabilities which subsequently contributes to overall project team efficacy. It could therefore be concluded that vigor is a critical engagement indicator and whoever contains it, is more likely to associate with others driven by the perceived individual capabilities.

From the dedication perspective, the study highlights that project team efficacy is more likely to improve whenever stakeholders are dedicated. This is a communication to all projects to implement dedication enhancers to improve project team efficacy. The study concludes so because dedicated people are more enthusiastic, inspired, and proud in the job than the less dedicated people. They are more likely to feel confident in themselves as well as the people they deal with. In the same context, Schaufeli (2013) mentioned that people who are highly dedicated get motivated so easily. Therefore, they tend to find all possible means of executing tasks to fulfill both their individual and organizational objectives. In the same line, Missonier and Fedida (2014) affirmed the need to stimulate dedication as a conduit for enhancing project team efficacy. Therefore, the communication that this study communicates is the fact that once stakeholders are dedicated, the more they would feel confident to work individually or in groups. They would perceive their work as full of meaning and purposeful; and they will consider tasks challenging but not difficult, something which would enhance collectivism in workplaces.

The findings further reveal that the absorption of stakeholders is necessary for enhancing project team efficacy. These results demonstrate that both perceived team and individual capabilities are more likely to mushroom whenever stakeholders are engaged. The findings are in line with previous works of Heravi et al., (2015) who concurred that the trilogy of engagement is fundamental in increasing confidence, creating a positive attitude and belief among individual members. Bal et al., (2013) pointed out that project team efficacy has an inclement on whether people are absorbed or not. This study argues that since absorption makes employees feel happy when working intensely, feel immersed in their work and find it difficult to detach from the job, it is from such attitude that is likely to drive perceived team efficacy. It is equally important to note that people who exhibit absorption behavior find it difficult to detach from their work, and in this study's perspective, such determina- tion is more likely to make people believe that they can still bounce back even when they fail to meet specific project obligations or even complete tasks without any form of guidance. Kaur and Lodhia (2018) also commented that internal stakeholder engagement, especially absorption increases the active participation of stakeholders which makes them more confident and efficaciously determined to work as a team. This is because such stakeholders would be sure of their ability to add value through contributing. In conclusion, the findings propose that projects should seek the best strategies for enhancing absorption, dedication, and vigor to enhance project team efficacy.

\section{Organizational Support and Project Team Ef-}

\section{ficacy}

The findings ascertained that organizational support is one of the factors which are necessary for enhancing project team efficacy. The findings suggest that projects can be hopeful that perceived team capabilities and perceived individual capabilities would be stimulated as long as people perceive that their organizations are offering them the best support depicted in managerial support, resource allocation, and job condition. This is consistent with Drouin and Bourgault (2013) who emphasized that organizational support increases supervisors' confidence in the team which reinforces their confidence. In addition, Ibrahim et al., (2016) stated that intensive organizational support is an important strategy for developing a team's efficacy because it changes the perception of individual team members towards their organization. This message portrayed by this study is that projects should offer organizational support to employees whenever they seek to project team efficacy.

Organizational support is a multifaceted component explained by subcomponents of managerial support, resource allocation, and job condition, and this study reveals that the existence of each of these attributes has a direct linkage with project team efficacy. Jain et al., (2013) and Ahmed and Nawaz (2015) equally explain organizational support as a potential contributor to project team efficacy. They concur that organizational support makes employees believe that they are resourceful and encourages people to work in teams to match the expectations of their supervisors in the shortest period possible. Therefore, the study emphasizes that projects should not just consider offering organizational support through just one attribute but 
rather seek the right mechanism through which all three issues could be addressed. This has a backing of literature, especially Winter and Weng (2015) who pointed out that when supervisors are confident that their team can deliver even under minimum supervision, they offer employees some level of freedom to execute tasks the way they feel would stimulate efficiency. The motive of this is to improve job conditions for employees.

Notable, the findings demonstrate that project team efficacy is more likely to manifest where project managers are willing to provide equipment whenever requested or where the other team members are willing to support colleagues. Indeed, this could be the reason why Kennedy et al., (2009) suggested that organizational support is indispensable in promoting project team efficacy. In the same regard, Newton (2015) emphasized that organizational support stimulates commitment, aggressiveness and stimulates confidence and trust amongst individual members within a given team. More still, the findings indicate that whenever supervisors are willing to provide team members with time-off whenever they request for one, take into consideration the goals and values of team members and where co-workers are willing to contribute handsomely to the happiness of others, the more likely perceived team efficacy. This is consistent with Wikhamn and Hall (2012) who asserted that organizational support enhances affective commitment and collectivism of members where they relate to the company with a "we" as opposed to "I" attitude. These findings, therefore, suggest that emphasis should be directed towards two critical issues; creating a platform where team members are made to believe that they are known to become more aggressive and where supervisors are willing to listen to their team members in their subsequent submissions.

Furthermore, the findings ascertained that it is necessary to provide team members with managerial support to enhance project team efficacy. Notable, findings demonstrate that whenever the project cares about the opinions of team members and where supervisors frequently encourage subordinates as they execute tasks and responsibilities, the more they would enhance their perceived individual and team capabilities. On the contrary, Afzali et al., (2014) revealed that irrespective of the high levels of organizational support, efficacy is bound to improve among individuals who strongly endorse the norm of reciprocity as applied to the employee-employer relationship. Notwithstanding, this study is more comprehensive in the manner that it examines component by component. Perhaps, the conclusive remarks by Afzali et al., (2014) are based on an aggregate of many aspects of organizational support, yet employees react differently depending on how organizational support is rendered. This study, therefore, provides a platform upon which project managers can intensify managerial support. For most of the studies, much as managerial support has highly been hailed, there are relatively few studies that have gone further to highlight managerial support enhancers. This serves as the gist upon which this study capitalizes to add value to the existing literature. Except for most scholarly works, this study highlights that the best mechanism through which project managers should provide good job conditions, allocate resources and offer managerial support to enhance organizational support and subsequently project team efficacy.

\section{Project Team Efficacy and Project Success}

Findings obtained a positive relationship between project team efficacy and project success. In the context of these findings, it is revealed that enhancing project team efficacy is likely to improve project success. Therefore, as project managers are actively seeking how best they can deliver projects within time, scope, budget, and meet beneficiary satisfaction, this study provides a partial solution to this. These findings concur with findings such as Aronson (2015) who postulated that project team efficacy increases innovativeness with much respect from each team member which to a very large extent enables projects to succeed. Worth noting, Kähkönen et al., (2013) indicated that project team efficacy stimulates confidence among individual team members which prompts them to devote extra time in whatever they do for successful project execution. In other words, there is a need to give special attention to project team efficacy to increase project success.

Specifically, the study postulate that both perceived team capabilities and perceived individual capabilities are necessary as far and project success enhancement is concerned. Likewise, Braun et al., (2012) suggest that with team efficacy in place, the focus of the group is to ensure that the project is executed as expected. The notable, findings highlight that whereas it is important to en- 
hance both perceived individual capabilities and perceived team capabilities, putting much emphasis on the latter is more likely to intensify project success. These findings communicate that project managers should prioritize practices that are aimed at stimulating perceived team capabilities as opposed to perceived individual capabilities to intensify project success. Moreover, the findings postulate to project managers that they should also seek for perceived individual enhancers to stimulate project success. A comparative analysis of the findings of the current study along with other subsequent studies reveals that almost no study has scrutinized the potential of sub-constructs under project team efficacy. Notable, Salas et al., (2015) conclusive remarks were general suggesting that project team efficacy increases team cohesion which subsequently enhances project success. On the other hand, Kraus and Insurance (2016) also asserted that project teams with considerable levels of efficacy experience greater focus, determination, and engagement in what they do to increase project success. Therefore, this study is exceptional in the sense that project team efficacy is not just concluded as a block, but rather in subcomponents.

For instance, the study reveals that where the team believes that even when things are not well, they can perform, where they enjoy working together as a group or where they consider their team as resourceful, the more they are likely to meet deadlines, effectively monitor spending, fulfill deadlines and the more likely they would work closely to fulfill the problems of beneficiaries. This is in line with Azmy (2012) who postulated that perceived group efficacy increases encourage individual members to work together and share views that can enable the project to fulfill its objectives within the required time, cost, scope and meet the expectations of beneficiaries. In the same context, the finding asserts that it is necessary for team members to believe that they are an effective team and to believe in success rather than failure as such attitude is bound to increase the aggressiveness of teams and hence project success. With the same view, Young and Samson (2009) indicated that team efficacy further promotes capability to handle project tasks within schedule which subsequently contributes to the overall project success.

On the other hand, the study affirms that perceived individual capabilities are essential in en- hancing project success. This study strongly believes that individual productivity emanates from what they believe and feel confident about. Earlier, Kent and Giles (2017) asserted that aggressiveness, determination, perseverance, and patience as well as a positive attitude towards executing tasks and responsibilities depend upon individual capabilities. In essence, this study argues that for projects to improve executing activities timely, within the budget, scope, and meet beneficiary expectations, they should have project members who have a positive attitude regarding their ability to complete tasks even when there is no one to monitor them. More so, such individuals should believe that their skills are valuable to the project and believe that they can complete tasks as expected, then the likelihood of completing projects within time increases. This concedes with Kraus and Insurance's (2016) earlier observation where they stated that considerable levels of efficacy are dependent upon individual focus, determination, and engagement in what they do, yet these actions are critical in stimulating project success. Overall, the findings here suggest that project success is a matter of perception. Such perception is either inclined to specific individuals or overall teams, and accordingly project managers should bear this in mind if they are to increase the likelihood of ensuring that the projects not only fulfill the traditional time, cost, and scope objectives but also stretch further to satisfy the beneficiaries.

\section{Mediating Effect of Project Team Efficacy}

This study obtained that project team efficacy is a significant mediator in the relationship between internal stakeholder engagement, organizational trust, and project success. Furthermore, the findings obtained that project team efficacy significantly mediates the relationship between internal stakeholder communication and project success as well as the relationship between organizational support and project success. The mediation effect of project team efficacy is relatively limited, and this study is potential value-adding research. Instead, most of the prevailing literature is for direct influence towards project success. Notable, a study by Aaltonen and Kujala (2016) affirms that internal stakeholder engagement directly predicts project success. Kivits (2013) also complement that when stakeholders are engaged, the project is in a position to eliminate conflicts and increase cooperation between the firm and the stakeholders which reduces time redundancy. About organizational 
support, Lancaster and Di Milia (2014) indicate that its potential lies mainly in its ability to determine the level of commitment, low intention to leave, and increased employee performance. This, therefore, signifies that the potential for organizational support to influence project success is more indirect. Similarly, Egriboyun (2015) revealed that organizational support results in positive employee outcomes which serve as a precondition for attitudinal, behavioral tendencies. The current study, therefore, reveals that both internal stakeholder engagement and organizational support significantly predict project success, although indirectly through project team efficacy.

Although, literature is not clear about the indirect relationship that exists between organizational support and project success as well as internal stakeholder engagement and project success, most of their presentations impliedly recognize the same. For instance, a study by Ahmed and Nawaz, (2015) stated that organizational support potentially changes attitude and behavior to work hard, but does not necessarily improve project success. Similarly, previous work by Ojwang and Bwisa (2014) indicates that engaged stakeholders support project activities, create among other stakeholders, and advise project managers on how best the project activities can be implemented within the communities for a sustainable project. On the other hand, Ojwang and Bwisa (2014) highlighted that much as engaged stakeholders' supports are necessary for project success, it may require the intervention of other factors. Therefore, it is conclusive that much as organizational support and internal stakeholder engagement is critical in project success, with the intensification of project team efficacy, projects are bound to meet time, scope, budget, and beneficiary satisfaction much easily.

Notwithstanding, the finding observed that much as all variables of internal stakeholder engagement, organizational support, and project team efficacy are significant in stimulating project success, project managers need to direct most emphasis towards project team efficacy. These findings are exposed to more debate as different scholars have expressed different views. Notable, Bal et al., (2013) expressed that the most important component of project success is internal stakeholder engagement. They suggested that internal stakeholders have a direct inclination to the project activities and are supposed to actively participate in executing activi- ties timely, efficiently, and effectively if projects are to be successful. Nevertheless, Ibrahim et al., (2016) as well as Ahmed and Nawaz, (2015) suggest organizational support if project success is to be achieved. These studies suggest that intensive organizational support is an important strategy for creating good working conditions where people can easily contribute to the project through decisions. Although this is the case, none of such studies derives such a conclusion after evaluating project team efficacy. This study is unique in the sense that it ascertains findings in a study in which the weaknesses of previous studies are addressed. The study's conclusive remarks are based on internal stakeholder engagement, organizational support, and project team efficacy in a single study. These findings could firmly be relied upon for more realistic decisions.

The implication of these results is that project success is dependent upon the team members who are directly involved in the execution of tasks and responsibilities. As long as they are confident and believe in success, the projects are more likely to follow suit. This is in line with Yaakobi and Weisberg (2018) who revealed that individuals with greater self-efficacy exhibit more willingness to work extra time and are creative enough to make contingent decisions to ensure that the project sticks to plan. Further still, Braun et al., (2012) assert that project team-efficacy prompts commitment and acceptance of difficult and challenging tasks which ultimately enhances project success. In other words, it is revealed that much emphasis should be directed towards the perception of team members because it determines the attitude and behavioral tendencies of members as they execute project tasks and obligations. Therefore, as they put into practice the decisions of top and middle managers, they should have the confidence and belief that they can turn things around. This is so because one's perception is a precondition for determining aggressiveness and self-drive towards project objectives.

Notable, the findings indicate that it is important to maintain team members with high perceived individual capabilities. In this case, such individuals would keep a high working spirit, feel confident about their skills and bounce back easily, and this is bound to increase efficiency and effectiveness in the implementation of project activities. This concurs with Aronson (2015) who revealed that project team efficacy increases innovativeness with 
much respect from each team member which to a very large extent enables projects to succeed. Similarly, Braun et al., (2012) suggest that with team efficacy in place, the relationship and focus of the group increases which prompts a collective effort to execute project activities as planned. This explains why it is necessary to consider uplifting perceived team capabilities in project management.

In addition, when team members are confident that they can complete project tasks as expected and work effectively without the guidance of any supervisor, the more they would perform, and such performance would have a triple-down effect on project success. These findings are in line with Kent and Giles (2017) who postulate that perceived team capabilities are a precondition for a project team's ability to set goals and aspirations, outcome expectations, and effective tendencies. van Emmerik et al., (2011) equally revealed that greater perceived team efficacy not only depicts individual self-efficacy but also provides much expectation that the project objectives would be executed as expected. Precisely, the level of perceived team capabilities increases confidence, promotes innovativeness, quality, and efficiency, which are necessary for guaranteeing project success. Based on the perceived team capabilities, the findings emphasize that when the project team is composed of members who consider other team members as resourceful and effective no matter how challenging the task are bound to enjoy working together and supporting each other to collectively execute project goals within the set time targets, budget, and scope. Such team members are also bound to ensure that their actions satisfy beneficiaries.

\section{Conclusion}

The study identified key concepts of relevance including; internal stakeholder engagement, organizational support, and project team efficacy and how they influence project success. It proved that projects need to have internal stakeholders who are highly vigorous, dedicated, and fully absorbed to promote the realization of project success. Therefore, the project manager should pay significant attention to identifying and putting into action the engagement enhancers. Similarly, the findings ascertained that organizational support is not an exception either as far as seeking project success is concerned. This prompts project managers to ensure that they avail good working conditions, supervisory support, and fair allocation of resources to stimulate the aggressiveness and commitment of team members. Findings also hailed project team efficacy as the most ideal solution to significantly influencing project success. In this essence, it is recognized that perceived individual capabilities, perceived team capabilities, and performance feedback of members are necessary.

Precisely, the study communicates that perception drives aggressiveness, belief, and attitude that members would rely on, to either feel confident or not. In the mediation effect relationship, the study affirmed that project team efficacy is only significant in the relationship between organizational support and project success. On the other hand, project team efficacy was found not significant in mediating the relationship between internal stakeholder engagement and project success. This postulates that where vigor, dedication, and absorption prevail, so does project team efficacy because they are both emotionally driven. Organizational support only creates satisfaction, but not confidence and belief as far as execution of projects is concerned. In sum, the study indicates that where internal stakeholders are engaged, they are bound to work efficaciously, while they provide organizational support and they should seek further means of stimulating team efficacy to succeed in projects.

\section{Recommendations}

Based on the findings, the following recommendations are put forward;

Delegate responsibilities to team members.

Increase communication within teams and ensure that a two-way approach is applied.

Team leaders should understand the strength and weaknesses of each team member and seek how to capitalize on their strengths.

Lead by example so that team members can easily emulate.

Hold meetings frequently to update team members of the progress, their achievements, and their expectations.

\section{Limitations of the Study}

The questionnaire was structured with closedended questions which suppressed the views and opinions which would have enabled the study to understand the subject matter more.

This study adopted a cross-sectional research approach where all results contained herein were based on data that was obtained just once or in 
a snapshot. Some of the responses views held by individuals may change over the years.

\section{Areas for further study}

i.) Relationship between work-life balance and project success among donor-funded projects.

ii.) Longitudinal analysis of the relationship between internal stakeholder engagement, organizational support, project team-efficacy, and project success among USAID donor projects in Uganda

\section{ACKNOWLEDGEMENT}

This work would not have been possible without the financial support of Mr. John Tveiten. I am especially indebted to Mr. Oyango Fredrick and Mr. Jae Song who motivated me and has been supportive of my career goals. They worked actively to provide me with guidance and information about USAID aided projects that backed my research.

I am grateful to all of those with whom I have had the pleasure to work with during this project. You provided me with extensive personal and professional guidance and taught me a great deal about life.

I would especially like to thank Prof. Bagire Vincent my teacher and mentor, he has taught me more than I could ever give him credit for here.

Nobody has been more important to me in the pursuit of this Degree than my boys; Clive Jyson and Kyle Osteen Muyingos who provided me with unending inspiration and often encouraged me when the 'going got tough'. I would like to thank my best friend Teopista Ochora and Mum whose love and guidance are with me in whatever I pursue. They are my ultimate role models.

\section{A References:}

1. Aaltonen, K., \& Kujala, J. (2016). Towards an improved understanding of project stakeholder landscapes. International Journal of Project Management, 34(8), 1537-1552. https://doi.org/10.1016/j.ij proman.2016.08.009

2. Afzali, A., Arash Motahari, A., \& HatamiShirkouhi, L. (2014). Investigating the influence of perceived organizational support, psychological empowerment and organizational learning on job performance: an empirical investigation. Tehnički vjesnik, 21(3), 623-629.

3. Ahmed, I., \& Nawaz, M. M. (2015). Antecedents and outcomes of perceived organizational support: a literature survey approach. Journal of Management Development, 34(7), 867-880. https://doi.org/ 10.1108/JMD-09-2013-0115

4. Anantatmula, V.S. (2010). Project manager leadership role in improving project performance. Engineering Management Journal, 22(1), 13-22. htt ps://doi.org/10.1080/10429247.2010.11431849

5. Aronson, Z. H. (2015). An investigation of the role of project culture in team efficacy and success in project-based work. International Journal of Innovation and Technology Management, 12(06), 1-18. https://doi.org/10.1142/S021987701550027 3

6. Azmy, N. (2012). The role of team effectiveness in construction project teams and project performance (Master's Thesis, lowa State University)

7. Babbie, $E$ (2010) The practice of social research (13th Ed) Belmont, CA: Thomas Wadswoth.

8. Bal, M., Bryde, D., Fearon, D., \& Ochieng, E. (2013). Stakeholder engagement: Achieving sustainability in the construction sector. Sustainability, 5(2), 695-710. https://doi.org/10.3390/su5020695

9. Bandura, A. (1997). Collective efficacy. In A. Bandura, (Ed.), Self-efficacy: The Exercise of Control. New York: Freeman, pp. 477-525.

10. Bandura, A. (2000). Exercise of human agency through collective efficacy, Current Directions in Psychological Science, 9, 75-80. https://doi.org/10. 1111/1467-8721.00064

11. Baron, R. M., \& Kenny, D. A. (1986). The moderator-mediator variable distinction in social psychological research: Conceptual, strategic, and statistical considerations. Journal of personality and social psychology, 51(6), 1173. https://doi.org/ 10.1037/0022-3514.51.6.1173 PMid:3806354

12. Beleiu, I., Crisan, E., \& Nistor, R. (2015). Main factors influencing project success. Interdisciplinary Management Research, 11, 59-72.

13. Beringer, C., Jonas, D., \& Kock, A. (2013). Behavior of internal stakeholders in project portfolio management and its impact on success. International Journal of Project Management, 31(6), 830846. https://doi.org/10.1016/j.jpproman.2012.11.0 06

14. Blau, P. M. (1964). Exchange and power in social life. New York: John Wiley.

15. Boukanos, A. K. (2013). The criteria of project success (Master's Thesis, School of Business and Management of City University)

16. Braun, F. C., Avital, M., \& Martz, B. (2012). Action-centered team leadership influences more 
than performance. Team Performance Management: An International Journal, 18(3/4), 176-195. h ttps://doi.org/10.1108/13527591211241015

17. Budworth, M.H. (2011). Individual learning and group performance: the role of collective efficacy, Journal of Workplace Learning, 23(6), 391-401. https://doi.org/10.1108/13665621111154403

18. Chan, A. P., \& Chan, A. P. (2004). Key performance indicators for measuring construction success. Benchmarking: an international journal, 11(2), 203-221. https://doi.org/10.1108/146357704 10532624

19. Chuo, Y. H., Tsai, C. H., Lan, Y. L., \& Tsai, C. S. (2011). The effect of organizational support, selfefficacy, and computer anxiety on the usage intention of e-learning system in hospital. African Journal of Business Management, 5(14), 5518.

20. Cummings, T., \& Worley, C. (2005). Organizational Development and Change (9th Ed), Ohio, South-Western.

21. De Villiers, C., \& Van Staden, C. (2012). New Zealand shareholder attitudes towards corporate environmental disclosure. Pacific Accounting Review, 24(2), 186-210. https://doi.org/10.1108/01140 581211258470

22. de Wit, A. (1986, September). Measuring project success: An illusion. In Proceedings of the 18th Annual Seminar/Symposium (Montreal/Canada) (pp. 13-21).

23. Drouin, N., \& Bourgault, M. (2013). How organizations support distributed project teams: Key dimensions and their impact on decision making and teamwork effectiveness. Journal of Management Development, 32(8), 865-885. https://doi.org/ 10.1108/JMD-07-2012-0091

24. Egriboyun, D. (2015). The relationship between organizational trust, organizational support and organizational commitment, African Journal of Business Management, 9(4), 134-156. https://doi.o rg/10.5897/AJBM2014.7623

25. Eisenberger, R., Huntington, R., Hutchison, S. \& Sowa, D. (1986). Perceived organizational support, Journal of Applied Psychology, 71(3), 500-507. https://doi.org/10.1037/0021-9010.71.3.500

26. Field, A. (2009). Discovering Statistics using SPSS (3rd Ed), Sage Publishers, London.

27. Frandsen, F., \& Johansen, W. (2011). The study of internal crisis communication: towards an integrative framework. An International Journal, 16(4), 347-361. https://doi.org/10.1108/135632811 11186977
28. Freeman, R. E. (2010). Strategic management: A stakeholder approach. Cambridge university press. https://doi.org/10.1017/CBO978113919 2675

29. Freeman, R.E. (1984). Strategic Management: A Stakeholder Approach, Pitman, Boston, MA

30. Fulton, E. A., Jones, T., Boschetti, F., Chapman, K. L., Little, R. L., Syme, G., ... \& de la Mare, W. (2013). Assessing the impact of stakeholder engagement in management strategy evaluation. International Journal of Economics and Management Engineering, 3(2), 82-102.

31. Handzic, M., Durmic, N., Kraljic, A. \& Kraljic, T. (2016). An empirical investigation of the relationship between intellectual capital and project success, Journal of Intellectual Capital, 17(3), 471-483. https://doi.org/10.1108/JIC-01-2016-0004

32. Heravi, A., Coffey, V., \& Trigunarsyah, B. (2015). Evaluating the level of stakeholder involvement during the project planning processes of building projects. International Journal of Project Management, 33(5), 985-997. https://doi.org/10.1016/j.ijpr oman.2014.12.007

33. Ibrahim, H. I., Isa, A., \& Shahbudin, A. S. M. (2016). Organizational support and creativity: the role of developmental experiences as a moderator. Procedia Economics and Finance, 3(5), 509-514. htt ps://doi.org/10.1016/S2212-5671(16)00063-0

34. Jain, A. K., Giga, S. I., \& Cooper, C. L. (2013). Perceived organizational support as a moderator in the relationship between organizational stressors and organizational citizenship behaviors. International Journal of Organizational Analysis, 21(3), 313334. https://doi.org/10.1108/IJOA-Mar-2012-0574

35. Joslin, R., \& Müller, R. (2015). Relationships between a project management methodology and project success in different project governance contexts. International Journal of Project Management, 33(6), 1377-1392. https://doi.org/10.1016/j.ijproma n.2015.03.005

36. Kagolo, F. (2013, May 2). GAVI warns Uganda over misusing sh51b new funding, New Vision, Retrieved from https://www.newvision.co.ug/new_ vision/news/1318463/gavi-warns-uganda-misusin g-sh51b-funding

37. Kähkönen, K., Keinänen, M., \& Naaranoja, M. (2013). Core project teams as an organizational approach for projects and their management. Procedia-Social and Behavioral Sciences, 7(4), 369376. https://doi.org/10.1016/j.sbspro.2013.03.01 0 
38. Kaur, A., \& Lodhia, S. (2018). Stakeholder engagement in sustainability accounting and reporting: A study of Australian local councils. Accounting, Auditing \& Accountability Journal, 31(1), 338-368. h ttps://doi.org/10.1108/AAAJ-12-2014-1901

39. Kennedy, F. A., Loughry, M. L., Klammer, T. P., \& Beyerlein, M. M. (2009). Effects of organizational support on potency in work teams: The mediating role of team processes. Small Group Research, 40(1), 72-93. https://doi.org/10.1177/10464964083 26744

40. Kent, A. M., \& Giles, R. M. (2017). Preservice Teachers' Technology Self-Efficacy. SRATE Journal, 26(1), 9-20.

41. Kivits, R. A. (2013). Multi-dimensional stakeholder analysis: a methodology applied to Australian capital city airports (PhD thesis, Southern Cross University, Lismore, NSW.)

42. Koelmans, R.G. (2004, October). Project success and performance evaluation. In International Platinum Conference 'Platinum Adding Value', The South African Institute of Mining and Metallurgy (No. 229-236)

43. Kozlowski, S. W., \& Ilgen, D. R. (2006). Enhancing the effectiveness of work groups and teams. Psychological science in the public interest, 7(3), 77-124. https://doi.org/10.1111/j.1529-1006.2006.0 0030.x PMid:26158912

44. Kraus, A. J., \& Insurance, L. M. (2016). The Effect of Top Management Team Performance and Cohesion on Organizational Outcomes, A White Paper prepared by the Visibility Committee of the Society for Industrial and Organizational Psychology, 440 E Poe Rd, Suite 101 Bowling Green, OH 43402

45. Krejcie, R.V. \& Morgan, D.W. (1970). Determining sample size for research activities, Educational and Psychological Measurement, 30, 607-610. http s://doi.org/10.1177/001316447003000308

46. Kwesiga, P. (2014, July 26). US firm to deliver HIV/AIDS services in Uganda, New Vision, Retrieved from https://www.newvision.co.ug/new_vision/ne ws/1303846/us-firm-deliver-hiv-aids-services-uga nda (Accessed June 8, 2018).

47. Lancaster, S. \& Di Milia, L. (2014). Organizational support for employee learning: An employee perspective, European Journal of Training and Development, 38(7), 642-657. https://doi.org/10.1108/ EJTD-08-2013-0084

48. Lechler, T. G., \& Dvir, D. (2010). An alternative taxonomy of project management structures: linking project management structures and project success. IEEE Transactions on Engineering Management, 57(2), 198-210. https://doi.org/10.1109/TEM. 2010.2044441

49. Likert, R. (1961). New Patterns of Management, McGraw-Hill, New York, NY.

50. Liu, J., Liu, X., \& Zeng, X. (2011). Does transactional leadership count for team innovativeness? The moderating role of emotional labor and the mediating role of team efficacy. Journal of Organizational Change Management, 24(3), 282-298. http s://doi.org/10.1108/09534811111132695

51. Maxwell, J. A. (2012). The Validity and Reliability of Research: A Realist Perspective. In D. Wyse, L. E. Suter, E. Smith, and N. Selwyn (Eds.) (2017), The BERA/SAGE Handbook of Educational Research. London: SAGE Publications, pp. 116-140. https://d oi.org/10.4135/9781473983953.n6

52. Missonier, S., \& Fedida, L.S. (2014). Stakeholder analysis and engagement in projects: From stakeholder relational perspective to stakeholder relational ontology. International Journal of Project Management, 32(7), 1108-1122. https://doi.org/10. 1016/j.jproman.2014.02.010

53. Morris, P. W. (1983). Managing project interfaces: key points for project success. Project management handbook, 2, 16-55. https://doi.org/1 0.1002/9780470172353.ch2

54. Newton, P. (2015). Managing a Project Team. Project Skills, available on www. free-managementebooks. com/dldebk-pdf/fme-project-team. pdf, 22-26.

55. Nunnally, J. C. (1978). Psychometric theory (2nd ed.). New York: McGraw-Hill.

56. Ojwang, W. O., \& Bwisa, H. M. (2014). Role of Participatory Management in the Sustainability of Constituency Development Fund Projects: A Case Study of Maragua Constituency. International Journal of Academic Research in Business and Social Sciences, 4(10), 108-127. https://doi.org/10.6007/IJ ARBSS/v4-i10/1212

57. Parker, D. W., Kunde, R., \& Zeppetella, L. (2017). Exploring communication in project-based interventions. International Journal of Productivity and Performance Management, 66(2), 146-179. htt ps://doi.org/10.1108/JJPPM-07-2015-0099

58. Phillips, R., Freeman, R. E., \& Wicks, A. C. (2003). What stakeholder theory is not. Business ethics quarterly, 13(4), 479-502. https://doi.org/10. 5840/beq200313434 
59. Proctor, C. R. (2014). Effective organizational communication affects employee attitude, happiness, and job satisfaction (Doctoral dissertation, Southern Utah University. Department of Communication. 2014.).

60. Rhoades, L. \& Eisenberger, R. (2002). Perceived organizational support: a review of the literature, Journal of Applied Psychology, 87(4), 698714. https://doi.org/10.1037/0021-9010.87.4.698 PMid:12184574

61. Salas, C. E., Radovic, D., Yuen, K. S., Yeates, G. N., Castro, O., \& Turnbull, O. H. (2015). Opening an emotional dimension in me: Changes in emotional reactivity and emotion regulation in a case of executive impairment after left front-parietal damage. Bulletin of the Menninger Clinic, 78(4), 301334. https://doi.org/10.1521/bumc.2014.78.4.301 PMid:25495435

62. Saunders, M., Lewis, P. and Thornhill, A. (2007), Research Methods for Business Students, 4th ed., Prentice Hall, London.

63. Savolainen, P., Ahonen, J. J., \& Richardson, I. (2012). Software development project success and failure from the supplier's perspective: A systematic literature review. International Journal of Project Management, 30(4), 458-469. https://doi.or g/10.1016/j.jproman.2011.07.002

64. Schaufeli, W. B. (2013). What is engagement?. In Employee engagement in theory and practice (pp. 29-49). Routledge. https://doi.org/10.4324/97 80203076965-10

65. Schaufeli, W.B. \& Bakker, A.B. (2004). Job demands, job resources, and their relationship with burnout and engagement: a multi-sample study. Journal of Organizational Behavior, 3, 293-315. htt ps://doi.org/10.1002/job.248

66. Shah, M., \& Naqvi, I. H. (2014). Impact of internal stakeholder's engagement on project portfolio management success, IT industry in Lahore, Pakistan. Science International (Lahore), 26(4), 17771782.

67. Sobel, M. E. (1982). Asymptotic confidence intervals for indirect effects in structural equation models. Sociological methodology, 13, 290-312. htt ps://doi.org/10.2307/270723

68. Tengan, C., \& Aigbavboa, C. (2017). Level of stakeholder engagement and participation in monitoring and evaluation of construction projects in Ghana. Procedia Engineering, 1(6), 630-637. http s://doi.org/10.1016/j.proeng.2017.08.051
69. Tuzun, K.I., \& Kalemci, A.R. (2012). Organizational and supervisory support in relation to employee turnover intentions. Journal of Managerial Psychology, 27(5), 518-534. https://doi.org/10.1108 /02683941211235418

70. USAID Annual Report (2017). USAID SUSTAIN Annual Report for the period OCTOBER 1, 2016 SEPTEMBER 30, 2017, Retrieved from http://sustai nuganda.org/content/project-reports.

71. van Emmerik, H., Jawahar, I. M., Schreurs, B., \& De Cuyper, N. (2011). Social capital, team efficacy and team potency: The mediating role of team learning behaviors. Career Development International, 16(1), 82-99. https://doi.org/10.1108/136204 31111107829

72. Weimar, E., Nugroho, A., Visser, J., Plaat, A., Goudbeek, M., \& Schouten, A. P. (2017). The Influence of Teamwork Quality on Software Team Performance. arXiv preprint arXiv:1701.06146.

73. Wikhamn, W., \& Hall, A. T. (2012). Social exchange in a Swedish work environment. International Journal of Business and Social Science, 3(23), 23-45.

74. Williams, T. (2016). Identifying success factors in construction projects: A case study. Project Management Journal, 47(1), 97-112. https://doi.org /10.1002/pmj.21558

75. Winston G.L, Kit F.P, \& Terence, R.L, (2007). Measuring employees' perception in small and medium-sized enterprises: A self-assessment scale. International journal of management science and Engineering management. 2(3), 229-238 https://do i.org/10.1080/17509653.2007.10671023

76. Winter, R., \& Weng, X. (2015). Negotiation and auditing self-efficacy's effect on auditor objectivity: negotiation strategy functioning as a mediator (Master's Thesis, Högskolan i Gävle).

77. Wu, G., Zhao, X., Zuo, J. \& Zillante, G. (2018). Effects of contractual flexibility on conflict and project success in megaprojects, International Journal of Conflict Management, 29(2), 253-278. https:/ /doi.org/10.1108/IJCMA-06-2017-0051

78. Yaakobi, E., \& Weisberg, J. (2018). Individual, group and organizational efficacies in predicting performance. Personnel Review, 47(2), 535-554. ht tps://doi.org/10.1108/PR-08-2016-0212

79. Yavas, U., \& Babakus, E. (2010). Relationships between organizational support, customer orientation, and work outcomes: A study of frontline bank employees. International Journal of Bank Market- 
ing, 28(3), 222-238. https://doi.org/10.1108/026523 21011036477

80. Yong, Y. C., \& Mustaffa, N. E. (2013). Critical success factors for Malaysian construction projects: an empirical assessment. Construction Management and Economics, 31(9), 959-978. https://doi.or $\mathrm{g} / 10.1080 / 01446193.2013 .828843$

81. Young, S.C., \& Samson, D. (2009). How team efficacy beliefs impact project performance: An empirical investigation of team potency in capital projects in the process industries (Doctoral dissertation, World Academy of Science).

82. Zhang, L., \& Fan, W. (2013). Improving performance of construction projects: A project manager's emotional intelligence approach. Engineering, Construction and Architectural Management, 20(2), 195-207. https://doi.org/10.1108/096999813 11303044 